\title{
Synthesis, Characterization and DFT Studies of Two Zinc(II) Complexes Based on 2-Isopropylimidazole
}

\author{
Jean Jacques Anguile1, Odette Nana Ngnabeuye ${ }^{2}$, Ndosiri Ndoye Bridget ${ }^{3}$, Tanyi Rogers Fomuta ${ }^{2}$, \\ Alvine Loris Djoumbissie ${ }^{2}$, Alain Charly Kuate Tagne ${ }^{2}$, Jean Ngoune ${ }^{2 *}$
}

${ }^{1}$ Department of Chemistry, University of Sciences \& Techniques of Masuku, Franceville, Gabon

${ }^{2}$ Department of Chemistry, University of Dschang, Dschang, Cameroon

${ }^{3}$ Department of Inorganic Chemistry, University of Yaounde 1, Yaounde, Cameroon

Email: jean.ngoune@univ-dschang.org

How to cite this paper: Anguile, J.J., Ngnabeuye, O.N., Bridget, N.N., Fomuta, T.R., Djoumbissie, A.L., Tagne, A.C.K. and Ngoune, J. (2018) Synthesis, Characterization and DFT Studies of Two Zinc(II) Complexes Based on 2-Isopropylimidazole. Open Journal of Inorganic Chemistry, 8, 105-124.

https://doi.org/10.4236/ojic.2018.84009

Received: July 30, 2018

Accepted: October 27, 2018

Published: October 30, 2018

Copyright $\odot 2018$ by authors and Scientific Research Publishing Inc. This work is licensed under the Creative Commons Attribution International License (CC BY 4.0).

http://creativecommons.org/licenses/by/4.0/

\begin{abstract}
Two novel coordination compounds, $\left[\mathrm{Zn}(\mathrm{L})_{2}(\mathrm{OOCH})_{2}\right] \quad$ (1) and $\left.\left[\mathrm{Zn}(\mathrm{L})_{3}(\mathrm{OCHO})\right](\mathrm{OCHO})\right] \cdot \mathrm{H}_{2} \mathrm{O} \quad$ (2) (where $\mathrm{L}=$ 2-isopropylimidazole, $\mathrm{C}_{6} \mathrm{H}_{10} \mathrm{~N}_{2}$ ) have been prepared by reaction of 2-isopropylimidazole with zinc(II) formate at room temperature using toluene as solvent. These compounds were characterized by elemental and thermal analyses, IR, ${ }^{1} \mathrm{HNMR}$ and ${ }^{13} \mathrm{CNMR}$ spectroscopies, single crystal X-ray diffraction and DFT studies. The $\mathrm{Zn}$ centers in $\mathbf{1}$ and $\mathbf{2}$ adopt pseudo-tetrahedral coordination geometries. Compound 1 crystallizes in the monoclinic system $P 2 / \mathrm{c}$ space group whereas compound 2 crystallizes in the $P$ - 1 space group of the triclinic crystal system. Several types of hydrogen intra-/intermolecular interactions are observed in these materials and extend into a two-dimensional leaf like network in 1 and a two-dimensional lattice of rectilinear pillars in $\mathbf{2}$. Compounds 1 and $\mathbf{2}$ were also optimized and their frontier molecular orbitals, global reactivity descriptors, molecular electrostatic potential, natural bond orbitals were investigated using density functional theory (DFT). In fact the induced structural differences from complex 1 to complex 2 led to the reduction of the frontier molecular orbital energy gap by $1.338 \mathrm{eV}$ and a decrease of the chemical hardness by $0.669 \mathrm{eV}$.
\end{abstract}

\section{Keywords}

Zinc(II) Complexes of 2-Isopropylimidazole, Thermogravimetric Analysis, ${ }^{1} \mathrm{H}-\mathrm{MR},{ }^{13} \mathrm{C}-\mathrm{MR}$, Crystal Structure, DFT Studies

\section{Introduction}

In recent years, the use of low-molecular weight coordination compounds as 
models for the active site in metalloproteins has gained much attention [1]. Also, the metal zinc is an essential element to all forms of livelihood, which is indispensable for the effective growth and development of living organisms and has beneficial therapeutic effects on diseases such as malaria and pneumonia [2]. Furthermore, Zinc complexes are part of a burgeoning network of bioactive inorganic molecules with a number of noteworthy biological activities [3]. In humans, zinc complexes have catalytic and structural functions in an estimated 300 enzymes, an example being carboxypeptidase A. This enzyme has been the subject of many recent reviews [4] [5]. In fact, carboxypeptidase A removes the C-terminal amino acid residue with an aromatic or branched aliphatic side chain from peptide substrate [6]. As one of the most intensively studied enzymes, it has contributed enormously to the elucidation of the catalytic mechanism of other zinc-containing proteolytic enzymes and served as a prototypical enzyme for a large number of pathologically important metalloenzymes. Carboxypeptidase A has also been used as a model in the development of inhibitor design strategies for medicinal purposes [7] [8] [9]. Another well-known zinc enzyme is carbonic anhydrase. Since its discovery in 1932, carbonic anhydrase has been the subject of intense study too [10]. It functions primarily in $\mathrm{CO}_{2}$ transport and excretion in blood [10] and is important in photosynthesis because of its ability to convert $\mathrm{CO}_{2}$ to $\mathrm{HCO}_{3}^{-}$reversibly [11]. Molecular, biochemical and genetic studies of carbonic anhydrase, analyzed in various tissues of many organs and plant species suggested its effect on a wide range of diverse biological processes, including $\mathrm{pH}$ regulation, gas and ion exchange, provision of bicarbonate for anaplerotic reactions, and fatty acid biosynthesis [12].

Recently, we have reproduced the active site of carboxypeptidase A through the synthesis and characterization of bisformatobis(2-isopropylimidazole)zinc(II) [13] and bis(2-ethylimidazole)bisformatozinc(II)-water (1/1),

$\left[\mathrm{Zn}\left(\mathrm{N}_{2} \mathrm{H}_{8} \mathrm{C}_{5}\right)_{2}(\mathrm{OCHO})_{2}\right] \cdot \mathrm{H}_{2} \mathrm{O}$ [14] by choosing a transition metal that is present in the naturally existing enzyme and ligands containing oxygen and nitrogen donor atoms. We now intend, on one hand, to enlarge this family of compounds and, on the other hand, to modify the active site of carboxypeptidase A, which was reproduced in bisformatobis(2-isopropylimidazole)zinc(II) [13]. This is realized through the replacement of one formate ligand in bisformatobis(2-isopropylimidazole)zinc(II) (1) by a 2-isopropylimidazole ligand and to evaluate the structural, electronic and enzymatic effects this may have. We report, herein, the synthesis, crystal structures and DFT studies of two model enzymes, bisformatobis(2-isopropylimidazole)zinc(II), [ $\left.\mathrm{Zn}\left(\mathrm{N}_{2} \mathrm{H}_{10} \mathrm{C}_{6}\right)_{2}(\mathrm{OOCH})_{2}\right]$ (1) and formatotris(2-isopropylimidazole) $\mathrm{Zn}$ (II) formate-water (1/2), $\left[\mathrm{Zn}\left(\mathrm{N}_{2} \mathrm{H}_{10} \mathrm{C}_{6}\right)_{3}(\mathrm{OCHO})\right](\mathrm{OCHO}) \cdot 2 \mathrm{H}_{2} \mathrm{O}(2)$.

\section{Experimental Section}

\subsection{Materials and Method}

All the chemicals were purchased from Aldrich and used without further purifi- 
cation. The syntheses of the complexes were carried out in air. Their melting points were uncorrected and measured using an SMP3 Stuart Scientific instrument operating at a $1.5^{\circ} \mathrm{C} / \mathrm{min}$ ramp rate. Elemental analysis $(\mathrm{C}, \mathrm{H}, \mathrm{N})$ was performed with a Fisson Instrument 1108 CHNS-O elemental analyzer, and the thermogravimetric analysis was performed using a Perkin-Elmer STA 6000 thermo-balance. The IR spectrum was recorded with a Perkin-Elmer System 100 FT-IR spectrophometer, meanwhile the NMR spectra $\left(400 \mathrm{MHz},{ }^{1} \mathrm{H}\right.$ and 100 $\mathrm{MHz},{ }^{13} \mathrm{C}$ ) were measured on a Mercury Plus Variant 400 spectrophotometer operating at room temperature. Proton chemical shift $(\delta)$ values are reported in parts per million (ppm) from $\mathrm{SiMe}_{4}$ (calibrating by internal deuterium solvent lock). Peak multiplicities are abbreviated as: singlet, s; doublet, d; triplet, t; quartet, $\mathrm{q}$ and multiplet, $\mathrm{m}$. Single crystals of the materials were coated with dry perfluoropolyether and placed at the tip of a glass fiber in a cold nitrogen stream [T = $173(2) \mathrm{K}]$ and mounted on a goniometer. The intensity data were collected on a Bruker-Nonius X8ApexII CCD area detector diffractometer using Mo- $\mathrm{K}_{\mathrm{a}}$-radiation source $(\lambda=0.71073 \AA)$ fitted with a graphite monochromator. The data collection strategy used was $\omega$ and $\varphi$ rotations with narrow frames (width of 0.50 degree). Instrument and crystal stability were evaluated from the measurement of equivalent reflections at different measuring times and no decay was observed. The data were reduced using SAINT [15] and corrected for Lorentz and polarization effects, and a semi-empirical absorption correction was applied (SADABS) [16]. The structure was solved by direct methods using SIR-2002 [17] and refined against all $F^{2}$ data by full-matrix least-squares techniques using SHELXL-2016/6 [18] minimizing $w\left[F o^{2}-F c^{2}\right]^{2}$. All the non-hydrogen atoms were refined with anisotropic displacement parameters. The hydrogen atoms of the compound were included in the calculated positions and allowed to ride on the attached atoms with isotropic temperature factors ( $U_{\text {iso }}$ values) fixed at 1.2 times those $U_{\text {eq }}$ values of the corresponding attached atoms. Theoretical studies were performed using the Gaussian 09 Revision-A.02-SMP program [19]. The vibrational frequencies, natural bond orbitals, electronic structures and geometries of the compounds were computed using density functional theory (DFT) at the B3LYP level of theory of the Lanl2DZ basis set. Molecular orbitals (MO) were visualized using the Gauss View 5.0.8 program. Global reactivity descriptors (chemical potential $(\mu)$ chemical hardness $(\eta)$ molecular electrophilicity $(w)$ and chemical softness) were computed from the energies of the highest occupied molecular orbital (HOMO) and lowest unoccupied molecular orbital (LUMO). For a donor atom (i) and an acceptor atom (j), the stabilization energy $\mathrm{E}^{(2)}$ associated with the electron delocalization between the donor and acceptor was obtained from the relationship; $\mathrm{E}^{(2)}=\Delta \mathrm{Eij}=\mathrm{q}^{\mathrm{i}} \mathrm{F}(\mathrm{ij}) /(\mathrm{Ej}-\mathrm{Ei})$ (where $\mathrm{qi}=$ orbital occupancy, $\mathrm{Ej}, \mathrm{Ei}=$ diagonal elements and $\mathrm{F}(\mathrm{ij})=$ off diagonal $\mathrm{NBO}$ fock matrix element.

\subsection{Syntheses}

2.2.1. Bisformatobis(2-Isopropylimidazole)Zinc(II), $\left[\mathrm{Zn}(\mathrm{L})_{2}(\mathrm{OOCH})_{2}\right]$ (1)

To a stirred solution of zinc(II) formate-water (1/2), $\mathrm{Zn}(\mathrm{OCHO})_{2} \cdot 2 \mathrm{H}_{2} \mathrm{O}(1.0 \mathrm{~g}$, 
$5.20 \mathrm{mmol}$ ) in $5 \mathrm{~mL}$ of toluene was added in small portions, solid of $\mathrm{L}=$ 2-isopropylimidazole, $\mathrm{C}_{6} \mathrm{H}_{10} \mathrm{~N}_{2}(1.15 \mathrm{~g}, 10.40 \mathrm{mmol})$ at room temperature. The solution was stirred overnight, whereby a solid precipitate was formed. The mixture was then filtered, washed trice, firstly with acetone and then twice with a DCM:cyclohexane (1:1) mixture and then dissolved in a DCM:n-hexane (1:1) mixture. The partial evaporation of the solvent gave colorless crystals of 1 in $80 \%$ yield of formula mass $375.73 \mathrm{~g} / \mathrm{mol}$ and melting point of $91^{\circ} \mathrm{C} \pm 2^{\circ} \mathrm{C}$. The results obtained from the analysis of the elements indicated $44.75 \% \mathrm{C}$ (Calc. 44.75\%), $14.95 \% \mathrm{~N}$ (Calc. 14.85\%) and 5.90\% $\mathrm{H}$ (Calc. 5.90), thus confirming the formula of 1 as $\mathrm{C}_{14} \mathrm{H}_{22} \mathrm{~N}_{4} \mathrm{O}_{4} \mathrm{Zn}$. This material was found to be slightly soluble in methanol and dichloromethane and insoluble in water.

\subsubsection{Formatotris(2-Isopropylimidazole)zinc(II) Formate-Water (1/2), $\left[\mathrm{Zn}(\mathrm{L})_{3}(\mathrm{OCHO})\right](\mathrm{OCHO}) \cdot 2 \mathrm{H}_{2} \mathrm{O}(2)$}

To a colorless solution of zinc(II) formate-water (1/2), $\mathrm{Zn}(\mathrm{OCHO})_{2} \cdot 2 \mathrm{H}_{2} \mathrm{O}(0.1 \mathrm{~g}$, $0.50 \mathrm{mmol})$ in toluene $(15 \mathrm{~mL})$ was slowly added $\mathrm{L}=2$-isopropylimidazole, $\mathrm{C}_{6} \mathrm{H}_{10} \mathrm{~N}_{2}$ (0.23 g, $2.0 \mathrm{mmol}$ ), which was maintain under agitation at room temperature. A solid precipitate formed within the reaction mixture was collected by filtration, washed with acetone and dissolved in a methanol:hexane (1:1) mixture. The quasi evaporation of the solvent from the mother liquor gave colorless crystalline solid of 2 at $82 \%$ yield, found to have a molar mass of $519.90 \mathrm{~g} / \mathrm{mol}$ and melted at $90^{\circ} \mathrm{C} \pm 2{ }^{\circ} \mathrm{C}$. Elemental analysis results obtained are, $48.28 \% \mathrm{C}$ (47.67), $16.83 \% \mathrm{~N}(16.80)$ and $7.19 \%(6.80)$, confirming $\mathrm{C}_{20} \mathrm{H}_{34} \mathrm{~N}_{6} \mathrm{O}_{6} \mathrm{Zn}$ as the empirical formula of 2.

\section{Results and Discussion}

\subsection{Spectroscopic Results}

The spectrum of compound 1 displays a weak band at $3136 \mathrm{~cm}^{-1}$ attributable to the valence vibration of the $\mathrm{N}-\mathrm{H}$ group of the 2 -isopropylimidazole fraction. The displacement of this frequency to a lower value is an indication that this group is engaged in hydrogen bond formation. The variable broad bands occurring between $2967-2823 \mathrm{~cm}^{-1}$ is due to C-H vibration of both the imidazole and the methyl groups of the ligand. The broad intense band observed between 1610 $1472 \mathrm{~cm}^{-1}$ is assignable to the vibrations of $\mathrm{C}=\mathrm{O}$ of the formate group, the $\mathrm{C}=\mathrm{C}$ and $\mathrm{C}=\mathrm{N}$ fractions of the imidazole unit. The intense band observed in the interval $1376-1298 \mathrm{~cm}^{-1}$ can be assigned to $\mathrm{C}-\mathrm{N}$ and $\mathrm{C}-\mathrm{C}$ vibrations of the imidazole ring. Even though the spectrum of 1 indicated the absence of $\mathrm{O}-\mathrm{H}$ vibration of water, compound 2 shows a slight deflection at $3300 \mathrm{~cm}^{-1}$ due to $\mathrm{O}-\mathrm{H}$ vibration, indicating the presence of uncoordinated water in the material. The medium band at $3074 \mathrm{~cm}^{-1}$ can be assigned to the valence vibration of $\mathrm{N}-\mathrm{H}$ group of 2-isopropylimidazole. This band expected between $4000-3200 \mathrm{~cm}^{-1}$ is shifted to lower frequency, indicating the involvement of this group in hydrogen bond formation. Furthermore, the broad band observed in the interval 2970 - 
$2684 \mathrm{~cm}^{-1}$ is due to $\mathrm{C}-\mathrm{H}$ vibration of the ligand. While the large intense bands appearing between $1595-1473 \mathrm{~cm}^{-1}$ is attributable to the $\mathrm{C}=\mathrm{C}$ and $\mathrm{C}=\mathrm{N}$ vibrations of the imidazole ring. The bands occurring from $1398 \mathrm{~cm}^{-1}$ to $1295 \mathrm{~cm}^{-1}$ arises due to $\mathrm{C}-\mathrm{C}$ and $\mathrm{C}-\mathrm{N}$ vibrations of the imidazolic unit.

Complex 1 was also subject to ${ }^{1} \mathrm{H}$ and ${ }^{13} \mathrm{C}-\mathrm{NMR}$ spectroscopies. The ${ }^{1} \mathrm{HNMR}$ spectrum shows five types of protons. The multiplet appearing at $\delta=1.2 \mathrm{ppm}$ is due to the resonance of the methyl protons of the isopropyl group $(6 \mathrm{H}, \mathrm{m}$, $\left.-\mathrm{CH}_{3}\right)$. Two singlets observed at $\delta=13.3 \mathrm{ppm}$ and $\delta=8.5 \mathrm{ppm}$ are attributable to the N-H imidazolyl proton $(1 \mathrm{H}, \mathrm{s},-\mathrm{NH})$ and the proton of the carboxyllate group $(1 \mathrm{H}, \mathrm{s}, \mathrm{HCOO})$ respectively. The multiplet observed at $\delta=6.8 \mathrm{ppm}$ is due to the resonance vibration of the $-\mathrm{CH}=\mathrm{CH}$-protons of the imidazole cycle $(2 \mathrm{H}$, $\mathrm{m},-\mathrm{CH}=\mathrm{CH}-$ ) while that occurring at $3.1 \mathrm{ppm}$ is assignable to the resonance vibration of the $-\mathrm{CH}$ - proton of the isopropyl substituent $(1 \mathrm{H}, \mathrm{m},-\mathrm{CH}-)$. On the other hand, the ${ }^{13} \mathrm{CNMR}$ spectrum indicated the presence of six types of carbon atoms in the complex. In fact, the peak at $\delta=169.3 \mathrm{ppm}$ is due to the carbon atom of the carboxyllate group (1C), while the methyl carbons of the isopropyl group resonates at $\delta=21.3 \mathrm{ppm}(2 \mathrm{C})$. This spectrum also shows two $\mathrm{sp}^{2}$ carbon atoms resonating at $\delta=117.5 \mathrm{ppm}(1 \mathrm{C})$ and $125.0 \mathrm{ppm}$ (1C) due to the carbon atoms of the $-\mathrm{CH}=\mathrm{CH}$ - groups of the imidazole ring and one $\mathrm{sp}^{3}$ carbon atom at $\delta=28.4 \mathrm{ppm}(1 \mathrm{C})$ arising from the resonance of the isopropyle's $-\mathrm{CH}-$ carbon atom. Finally, the peak observed at $\delta=155.9 \mathrm{ppm}$ is due to the $-\mathrm{C}=\mathrm{N}$ carbon of the imidazolyl ring.

\subsection{Results of Thermal Analyses}

These complexes were subjected to thermal analyses during which complex 1 was heated from $25^{\circ} \mathrm{C}-350^{\circ} \mathrm{C}$ while 2 was heated from $25^{\circ} \mathrm{C}$ to $450^{\circ} \mathrm{C}$ and the results obtained are illustrated on Figure 1 . The figures display two curves, one in red and the other in blue. The blue curves represent the change in mass of the samples as they are subjected to heat while the red curves indicate the variations in the heat content of the material during heating. Complex 1 (Figure 1(a)) is thermally stable up $100^{\circ} \mathrm{C}$, after which it underwent a $28.5 \%$ mass loss between $100^{\circ} \mathrm{C}-230^{\circ} \mathrm{C}$ corresponding to the departure of one 2 -isopropylimidazole molecule (Calc. 29.3\%). Moreover, the curve indicating the variation of the heat content indicates two endothermic processes at $106^{\circ} \mathrm{C}$ and $210^{\circ} \mathrm{C}$. The endothermic process observed at $106^{\circ} \mathrm{C}$ is associated with the melting of the material and has an enthalpy, $\Delta \mathrm{Hf}=7.0 \mathrm{~kJ} \cdot \mathrm{mol}^{-1}$. Meanwhile, Figure $1(\mathrm{~b})$ shows that 2 is thermally stable up to $60^{\circ} \mathrm{C}$, followed by a significant $55 \%$ weight loss in the interval of $90^{\circ} \mathrm{C}-230^{\circ} \mathrm{C}$ attributable to the departure of two molecules of uncoordinated water, two 2-isopropylimidazole molecules and one formate anion (Calc. $56 \%$ ). The heat change curve indicates four endothermic processes, one at $70^{\circ} \mathrm{C}$ and three between $185^{\circ} \mathrm{C}$ and $230^{\circ} \mathrm{C}$. The endothermic process at $70^{\circ} \mathrm{C}$ is associated with the melting of the material and has a transformation enthalpy, $\Delta \mathrm{H}_{\mathrm{f}}=$ $3.75 \mathrm{~kJ} \cdot \mathrm{mol}^{-1}$. The two endothermic processes around $185^{\circ} \mathrm{C}$ indicate the beginning of the progressive departure of $\mathrm{C}_{6} \mathrm{H}_{10} \mathrm{~N}_{2}, \mathrm{HCOO}^{-}$and $\mathrm{H}_{2} \mathrm{O}$ of the material. 


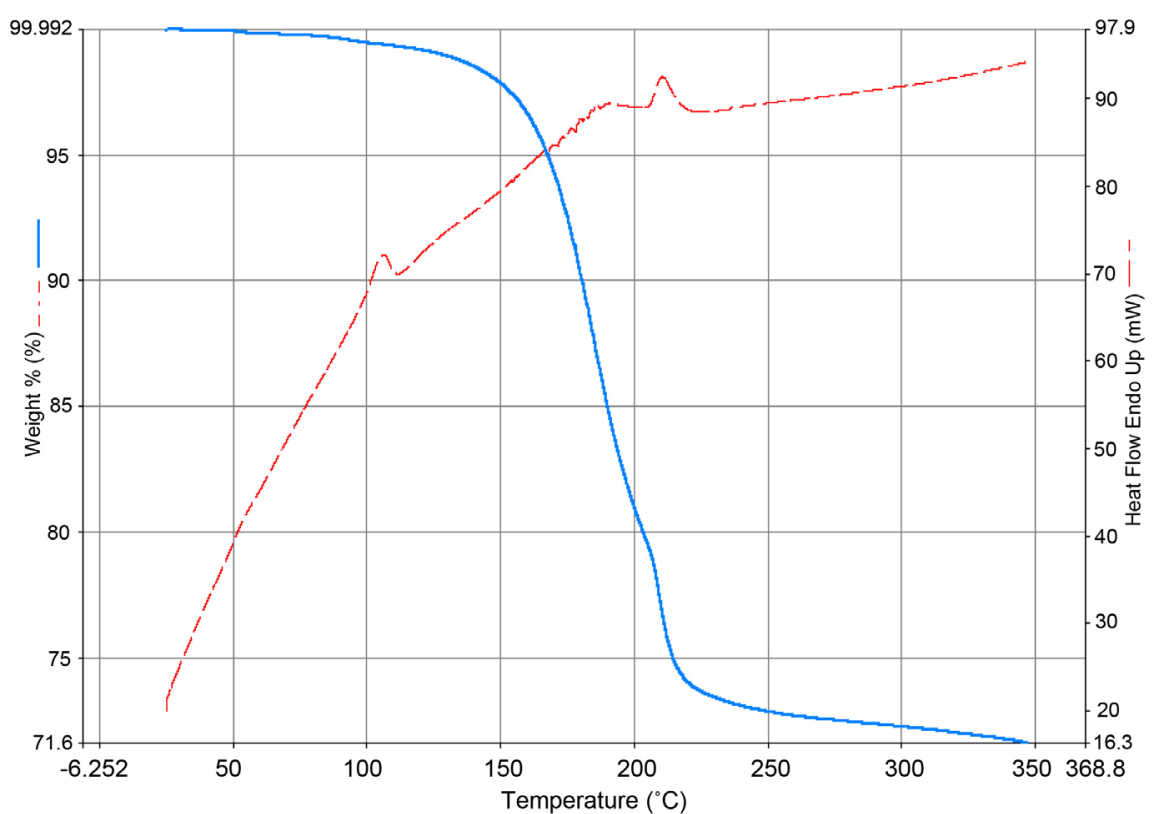

(a)

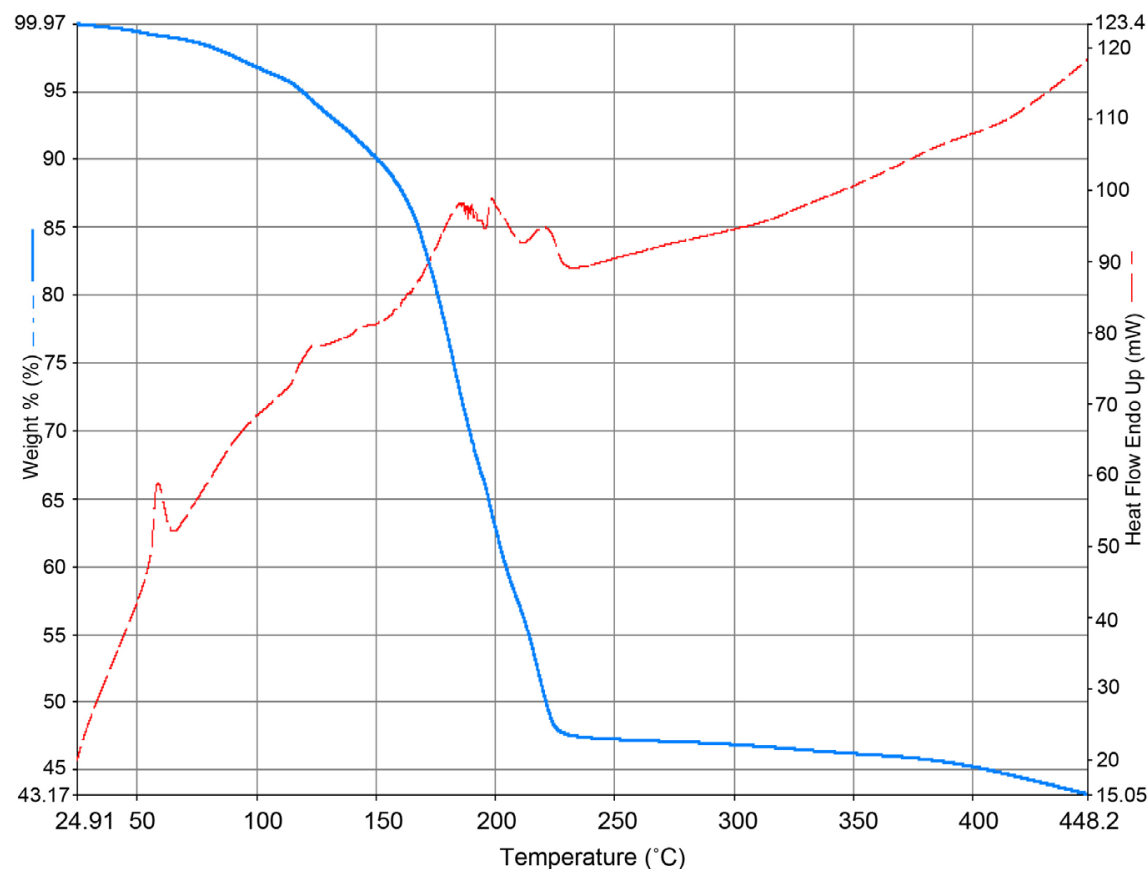

(b)

Figure 1. Thermogravimetric curves of (a) $\left[\mathrm{Zn}(\mathrm{L})_{2}(\mathrm{OOCH})_{2}\right]$ (1) and (b) $\left[\mathrm{Zn}(\mathrm{L})_{3}(\mathrm{OCHO})\right](\mathrm{OCHO}) \cdot 2 \mathrm{H}_{2} \mathrm{O}(2)$.

\subsection{Structural Determination}

Single crystals of the complexes were subjected to X-ray analyses and their MERCURY and ORTEP views are shown in Figure 2 and Figure 3 respectively. The unit cells in which these materials crystallize are shown in Figure 4 while the crystallographic data and the structural refinement details used in the full description of their molecular crystalline structures are summarized in Table 1. 


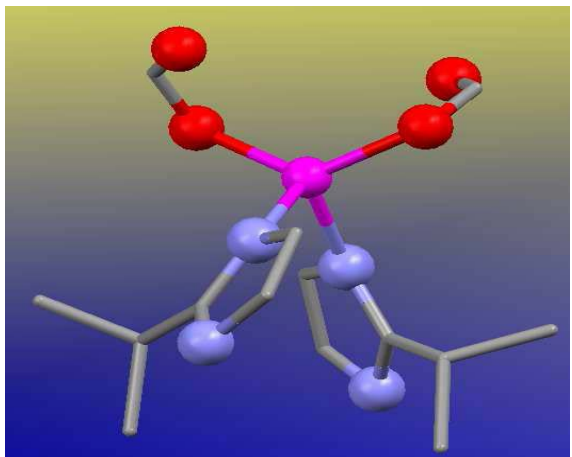

(a)

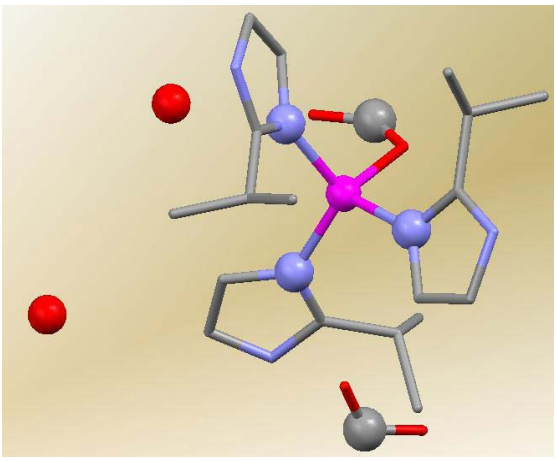

(b)

Figure 2. MERCURY View (ball and sticks) of (a) $\left[\mathrm{Zn}(\mathrm{L})_{2}(\mathrm{OOCH})_{2}\right]$ (1) and (b) $\left[\mathrm{Zn}(\mathrm{L})_{3}(\mathrm{OCHO})\right](\mathrm{OCHO}) \cdot 2 \mathrm{H}_{2} \mathrm{O}(2) . \mathrm{Zn}$ (pink), $\mathrm{N}$ (blue), $\mathrm{O}$ (red) (hydrogen atoms are omitted for the sake of clarity).

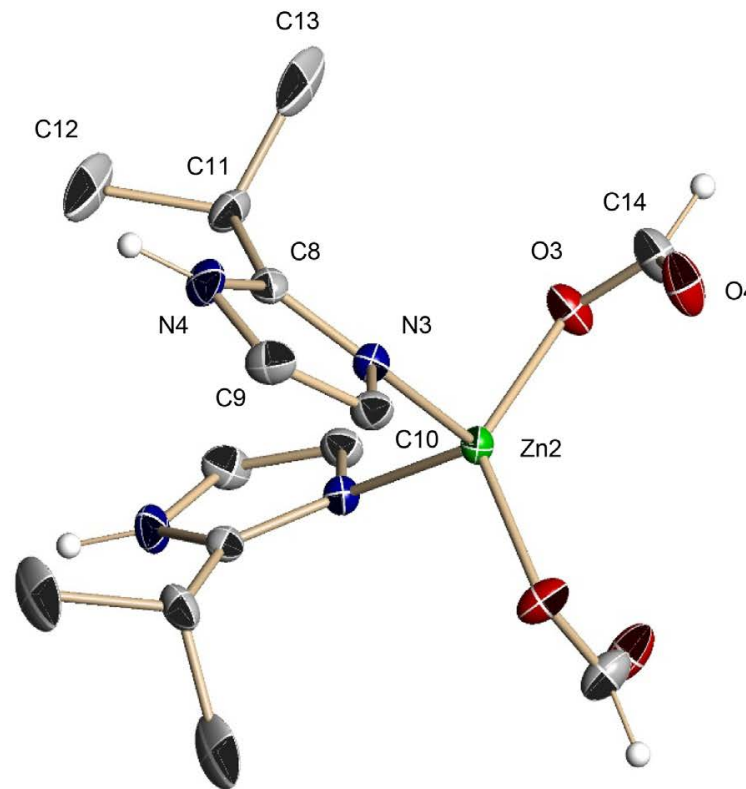

(a)

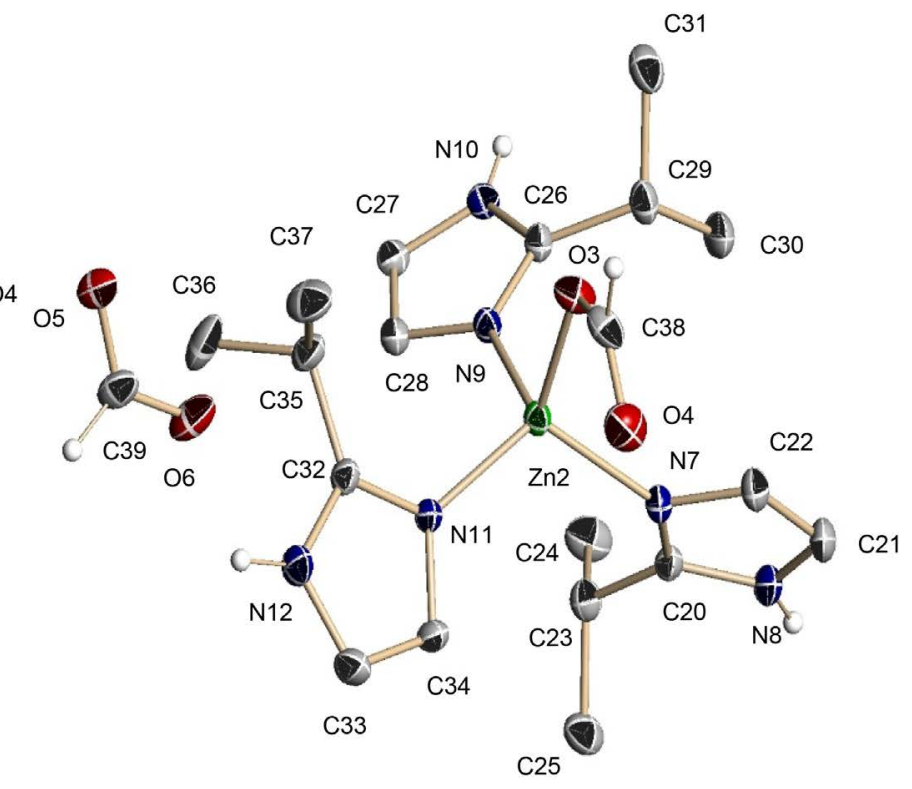

(b)

Figure 3. ORTEP View of the molecular crystalline structures of (a) $\left[\mathrm{Zn}(\mathrm{L})_{2}(\mathrm{OOCH})_{2}\right](1)$ and (b) $\left[\mathrm{Zn}(\mathrm{L})_{3}(\mathrm{OCHO})\right](\mathrm{OCHO}) \cdot 2 \mathrm{H}_{2} \mathrm{O}$ (2) showing atomic labelling.

The crystallographic data indicate that complex 1 crystallizes in the $P 2 / \mathrm{c}$ space group of the monoclinic system while complex 2 is found in the triclinic system with the $P$ - 1 space group. Actually, these compounds consist of a zinc atom situated at the center of a tetrahedral. This geometry is similar to what is observed in $\left[\mathrm{Zn}\left(\mathrm{OOCCH}_{3}\right)_{2}(\mathrm{pzH})_{2}\right]$ (where pzH = pyrazole) [20]. More so, the formate unit adopts a monodentate coordination mode, just as was noticed earlier in $\left[\mathrm{Zn}\left(\mathrm{N}_{2} \mathrm{H}_{8} \mathrm{C}_{5}\right)_{2}(\mathrm{OCHO})_{2}\right] \cdot \mathrm{H}_{2} \mathrm{O}$ [14]. In the neutral compound 1, the geometry around the zinc center is constructed by two nitrogen atoms ( $\mathrm{Zn}-\mathrm{N}=2.004 \AA$ ) from two 2-isopropylimidazole molecules and two oxygen atoms $(\mathrm{Zn}-\mathrm{O}=1.957$ $\AA$ ) from two formate units. Meanwhile, in compound 2, the geometry around the zinc atom is established by three nitrogen atoms $(\mathrm{Zn}(2)-\mathrm{N}(7)=1.990 \AA$, 


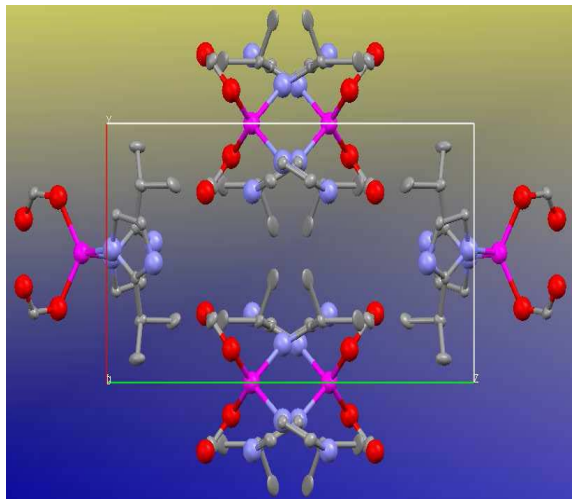

(a)

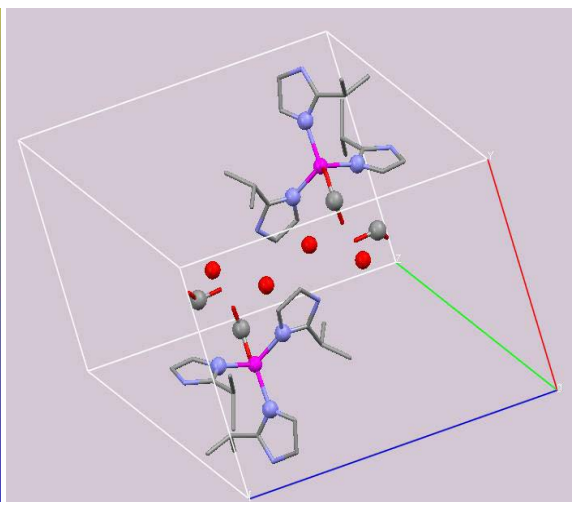

(b)

Figure 4. Unit cells of (a) $\left[\mathrm{Zn}(\mathrm{L})_{2}(\mathrm{OOCH})_{2}\right](1)$ and (b) $\left[\mathrm{Zn}(\mathrm{L})_{3}(\mathrm{OCHO})\right](\mathrm{OCHO}) \cdot 2 \mathrm{H}_{2} \mathrm{O}$ (2) in which they crystallize.

$\mathrm{Zn}(2)-\mathrm{N}(9)=2.000 \AA, \mathrm{Zn}(2)-\mathrm{N}(11)=1.970 \AA$ ) from three 2-isopropylimidazole ligands and one oxygen atom $(\mathrm{Zn}(2)-\mathrm{O}(3)=1.960 \AA)$ from a formate group, giving rise to a cationic $\left[\mathrm{Zn}\left(\mathrm{N}_{2} \mathrm{H}_{10} \mathrm{C}_{6}\right)_{3}(\mathrm{OCHO})\right]^{+}$coordination entity, one anionic formate counter ion and two hydrated water molecules. Some selected bond lengths and angles in the compounds are summarized in Table 2. The arrangement of the 2-isopropylimidazole ligands in the molecular structure of 1 creates $\pi-\pi$ interactions of the order $3.156 \AA$ to $5.149 \AA$ due to the proximity of the electronic cloud around the aromatic nuclei of 2-isopropylimidazoles. Moreover, some intermolecular hydrogen interactions observed in $\mathbf{1}$ and $\mathbf{2}$ are summarized on the Table 3 and Table 4. These interactions generate in the crystal lattice of 1 a two-dimensional leaf like structure shown in Figure 5 containing cavities of various sizes and shapes. Some pseudo-rectangular cavities of dimensions of $9.832 \AA \times 8.919 \AA$ for example, found within this crystal structure and having vertices occupied by the zinc atoms, are likely to accommodate small molecules. On the other hand, the interactions in $\mathbf{2}$ generate a two-dimensional crystalline lattice consisting of important rectilinear pillars (Figure 6), in which the anions and the cations alternate, leaving small cavities occupied by water molecules of crystallization and capable of inducing particular properties in the material.

\subsection{DFT Studies}

DFT studies were performed on both complexes, at the B3LYP level of theory, using the Lanl2DZ basis set in the gas phase. The optimized structures obtained are shown in Figure 7. The optimized structure of 1 shows a partial delocalization of the $\pi$-electron systems of the formate group and the imidazolyl rings. In the optimized structure of 2 , the $\pi$-electron systems of the formate groups and those of two imidazole ligands are partially delocalized while that of one imidazole moiety is completely delocalized. The geometric parameters of these optimized structures are summarized on Table 5 and Table 6 . All the bonds around the $\mathrm{Zn}$ (II) center in $\mathbf{1}$ and $\mathbf{2}$ are slightly elongated in the optimized structure with acceptable discrepancies ranging from $0.010-0.083 \AA$ in 1 and 0.024 - 
Table 1. Crystallographic data and structure refinement details of the complexes.

\begin{tabular}{|c|c|c|}
\hline Crystallographic data & Compound 1 & Compound 2 \\
\hline Chemical formula & $\mathrm{C}_{14} \mathrm{H}_{22} \mathrm{~N}_{4} \mathrm{O}_{4} \mathrm{Zn}$ & $\mathrm{C}_{20} \mathrm{H}_{34} \mathrm{~N}_{6} \mathrm{O}_{6} \mathrm{Zn}$ \\
\hline Molar mass & $375.73 \mathrm{~g} \cdot \mathrm{mol}^{-1}$ & $519.90 \mathrm{~g} \cdot \mathrm{mol}^{-1}$ \\
\hline Temperature & $173(2) \mathrm{K}$ & $173(2) \mathrm{K}$ \\
\hline Wavelength & $0.71073 \AA$ & $0.71073 \AA$ \\
\hline Crystal system & Monoclinic & Triclinic \\
\hline Space group & $P 2 / \mathrm{c}$ & $P-1$ \\
\hline Unit cell dimensions & $\begin{array}{c}\mathrm{a}=10.7670 \AA \mathrm{b}=15.0525 \AA \\
\mathrm{c}=15.1074 \AA \quad \alpha=90^{\circ} \\
\beta=132.458^{\circ} \gamma=90^{\circ}\end{array}$ & $\begin{array}{c}\mathrm{a}=11.61 \AA \mathrm{b}=14.94 \AA \\
\mathrm{c}=15.67 \AA \quad \alpha=77.4^{\circ} \\
\beta=82.6^{\circ} \gamma=86.7^{\circ}\end{array}$ \\
\hline Volume & $1806.4 \AA^{3}$ & $2629.0 \AA^{3}$ \\
\hline $\mathrm{Z}$ & 4 & 2 \\
\hline Density (calculated) & $1.382 \mathrm{mg} / \mathrm{m}^{3}$ & $1.2773 \mathrm{mg} / \mathrm{m}^{3}$ \\
\hline Absorption coefficient & $1.382 \mathrm{~mm}^{-1}$ & $0.972 \mathrm{~mm}^{-1}$ \\
\hline $\mathrm{F}(000)$ & 784 & 1064 \\
\hline Crystal size & $0.10 \times 0.08 \times 0.06 \mathrm{~mm}^{3}$ & $0.33 \times 0.22 \times 0.20 \mathrm{~mm}^{3}$ \\
\hline $\begin{array}{l}\text { Theta range for data } \\
\text { collection }\end{array}$ & $1.32^{\circ}$ to $30.52^{\circ}$ & $1.40^{\circ}$ to $30.54^{\circ}$ \\
\hline Index ranges & $\begin{array}{c}-15 \leq \mathrm{h} \leq 13,-20 \leq \mathrm{k} \leq 21 \\
16 \leq 1 \leq 21\end{array}$ & $\begin{array}{c}-16 \leq \mathrm{h} \leq 16,-19 \leq \mathrm{k} \leq 21 \\
-14 \leq 1 \leq 22\end{array}$ \\
\hline Reflection collected & 23,064 & 96,729 \\
\hline Independent reflection & $5510[\mathrm{R}(\mathrm{int})=0.0856]$ & $15,886[\mathrm{R}(\mathrm{int})=0.0509$ \\
\hline Completeness to theta & $99.4 \%$ & $98.9 \%$ \\
\hline Absorption correction & $\begin{array}{l}\text { Semi-empirical from } \\
\text { equivalents }\end{array}$ & $\begin{array}{c}\text { Semi-empirical from } \\
\text { equivalents }\end{array}$ \\
\hline Max and min. transmission & 0.9216 and 0.8741 & 0.8293 and 0.7397 \\
\hline Refinement method & $\begin{array}{c}\text { Full-matrix } \\
\text { least-squares on } \mathrm{F}^{2}\end{array}$ & $\begin{array}{c}\text { Full-matrix } \\
\text { least-squares on } \mathrm{F}^{2}\end{array}$ \\
\hline Data/restraints/parameters & $5510 / 2 / 219$ & $15,886 / 0 / 690$ \\
\hline Goodness -of-fit on $\mathrm{F}^{2}$ & 1.008 & 1.055 \\
\hline $\begin{array}{l}\text { Final } R \text { indices } \\
{[\mathrm{I}>2 \text { sigma(I)] }}\end{array}$ & $\mathrm{R} 1=0.0445, \mathrm{WR} 2=0.0869$ & $\mathrm{R} 1=0.0545, \mathrm{wR} 2=0.1367$ \\
\hline $\mathrm{R}$ indices (All data) & $\mathrm{R} 1=0.0941 ; \mathrm{WR} 2=0.1000$ & $\mathrm{R} 1=0.0756, \mathrm{wR} 2=0.1635$ \\
\hline Largest diff peak and hole & 0.653 and $-0492 \mathrm{e} \cdot \mathrm{A}^{-3}$ & 1.812 and $-0.691 \mathrm{e} \cdot \AA^{-3}$ \\
\hline
\end{tabular}

$\mathrm{R} 1=\Sigma / / \mathrm{F}_{\mathrm{a}} /-/ \mathrm{F}_{\mathrm{c}} / / \Sigma / \mathrm{F}_{\mathrm{a}} /, \quad \mathrm{wR} 2=\left[\Sigma\left(\mathrm{F}_{\mathrm{a}}^{2}-\mathrm{F}_{\mathrm{c}}^{2}\right)^{2} / \Sigma \mathrm{w}\left(\mathrm{F}_{\mathrm{a}}^{2}\right)^{2}\right]^{1 / 2}$.

$0.138 \AA$ in 2 . However, the $\mathrm{N}_{10}-\mathrm{Zn}_{9}-\mathrm{N}_{7}$ and $\mathrm{N}_{10}-\mathrm{Zn}_{9}-\mathrm{O}_{23}$ angles in $\mathbf{1}$ are enlarged, while the $\mathrm{O}_{23}-\mathrm{Zn}_{9}-\mathrm{O}_{18}$ angle is compressed in the optimized structure. In fact, the $\mathrm{N}_{10}-\mathrm{Zn}_{9}-\mathrm{N}_{7}$ angle which is increased from $103.34^{\circ}$ in the experimental structure to $115.86^{\circ}$ in the optimized structure shows an exaggerated disparity of $12.19^{\circ}$. Meanwhile, the discrepancy observed between the experimental angles and theoretical angles of $\mathrm{N}_{10}-\mathrm{Zn}_{9}-\mathrm{O}_{23}$ and $\mathrm{O}_{23}-\mathrm{Zn}_{9}-\mathrm{O}_{18}$ in the interval $4.06^{\circ}-5.57^{\circ}$ is 
Table 2. Selected bond lengths and angles in the title complexes.

\begin{tabular}{cccc}
\hline \multicolumn{4}{c}{ Compound $\left[\mathrm{Zn}(\mathrm{L})_{2}(\mathrm{OOCH})_{2}\right](1)$} \\
\hline Bonds & Lengths $(\AA)$ & Angles & $\left(^{\circ}\right)$ \\
\hline $\mathrm{Zn}(1)-\mathrm{O}(1)$ & 1.957 & $\mathrm{O}(1)-\mathrm{Zn}(1)-\mathrm{O}(1) \# 1$ & 121.11 \\
$\mathrm{Zn}(1)-\mathrm{O}(1)$ & 1.957 & $\mathrm{O}(1)-\mathrm{Zn}(1)-\mathrm{N}(1)$ & 111.80 \\
$\mathrm{Zn}(1)-\mathrm{N}(1)$ & 2.004 & $\mathrm{O}(1) \# 1-\mathrm{Zn}(1)-\mathrm{N}(1)$ & 103.79 \\
$\mathrm{Zn}(1)-\mathrm{N}(1)$ & 2.004 & $\mathrm{C}(7)-\mathrm{O}(1)-\mathrm{Zn}(1)$ & 117.92 \\
& & $\mathrm{C}(1)-\mathrm{N}(1)-\mathrm{C}(3)$ & 106.4 \\
\hline Bonds & Lempound $\left[\mathrm{Zn}(\mathrm{L})_{3}(\mathrm{OCHO})\right] \mathrm{OCHO} \cdot 2 \mathrm{H}_{2} \mathrm{O}(2)$ \\
\hline $\mathrm{Zn}(2)-\mathrm{N}(11)$ & 1.970 & $\mathrm{Angles}$ & $\left({ }^{\circ}\right)$ \\
$\mathrm{Zn}(2)-\mathrm{N}(7)$ & 1.990 & $\mathrm{~N}(7)-\mathrm{Zn}(2)-\mathrm{N}(9)$ & 105.20 \\
$\mathrm{Zn}(2)-\mathrm{N}(9)$ & 2.000 & $\mathrm{~N}(9)-\mathrm{Zn}(2)-\mathrm{O}(3)$ & 102.30 \\
$\mathrm{Zn}(2)-\mathrm{O}(3)$ & 1.960 & $\mathrm{~N}(7)-\mathrm{Zn}(2)-\mathrm{O}(3)$ & 111.40 \\
& & $\mathrm{~N}(11)-\mathrm{Zn}(2)-\mathrm{N}(7)$ & 116.30 \\
& & $\mathrm{~N}(11)-\mathrm{Zn}(2)-\mathrm{O}(3)$ & 109.60 \\
& & $\mathrm{~N}(11)-\mathrm{Zn}(2)-\mathrm{N}(9)$ & 111.20 \\
\hline
\end{tabular}

Symmetry transformations used to generate equivalent atoms: $\# 1-x+1, y,-z+3 / 2 \# 2-x, y,-z+1 / 2$.

Table 3. Hydrogen bonding interaction in the complex 1.

\begin{tabular}{ccccc}
\hline $\mathrm{D}-\mathrm{H} \ldots \mathrm{A}$ & $\mathrm{d}(\mathrm{D}-\mathrm{H})$ & $\mathrm{d}(\mathrm{H} \ldots \mathrm{A})$ & $\mathrm{d}(\mathrm{D} \ldots \mathrm{A})$ & $<(\mathrm{DHA})$ \\
\hline $\mathrm{N}(4)-\mathrm{H}(4 \mathrm{~N}) \ldots \mathrm{O}(2) \# 3$ & $0.894(17)$ & $1.907(19)$ & $2.770(3)$ & $162(3)$ \\
$\mathrm{N}(2)-\mathrm{H}(2 \mathrm{~N}) \ldots \mathrm{O}(4)$ & $0.886(17)$ & $1.895(17)$ & $2.774(3)$ & $172(2)$ \\
\hline
\end{tabular}

Table 4. Hydrogen bonding interaction in the complex 2.

\begin{tabular}{ccccc}
\hline $\mathrm{D}-\mathrm{H} \ldots \mathrm{A}$ & $\mathrm{d}(\mathrm{D}-\mathrm{H})$ & $\mathrm{d}(\mathrm{H} \ldots \mathrm{A})$ & $\mathrm{d}(\mathrm{D} \ldots \mathrm{A})$ & $<(\mathrm{DHA})$ \\
\hline $\mathrm{N}(8)-\mathrm{H}(8 \mathrm{~N}) \ldots \mathrm{O}(7 \mathrm{~A}) \# 1$ & 0.88 & 1.86 & $2.722(14)$ & 168.0 \\
$\mathrm{~N}(8)-\mathrm{H}(8 \mathrm{~N}) \ldots \mathrm{O}(7 \mathrm{~B}) \# 1$ & 0.88 & 1.81 & $2.672(13)$ & 167.4 \\
$\mathrm{~N}(4)-\mathrm{H}(4 \mathrm{~N}) \ldots \mathrm{O}(7 \mathrm{~B}) \# 2$ & 0.88 & 2.64 & $3.488(16)$ & 161.4 \\
$\mathrm{~N}(4)-\mathrm{H}(4 \mathrm{~N}) \ldots \mathrm{O}(7 \mathrm{~A}) \# 2$ & 0.88 & 2.24 & $3.066(12)$ & 156.6 \\
$\mathrm{~N}(4)-\mathrm{H}(4 \mathrm{~N}) \ldots \mathrm{O}(8 \mathrm{~B}) \# 2$ & 0.88 & 2.08 & $2.84(2)$ & 143.3 \\
$\mathrm{~N}(4)-\mathrm{H}(4 \mathrm{~N}) \ldots \mathrm{O}(8 \mathrm{~A}) \# 2$ & 0.88 & 1.98 & $2.740(18)$ & 143.6 \\
$\mathrm{O}(10)-\mathrm{H}(1 \mathrm{BO}) \ldots \mathrm{O}(6) \# 3$ & 0.85 & 2.32 & $3.031(7)$ & 141.9 \\
$\mathrm{O}(9)-\mathrm{H}(9 \mathrm{BO}) \ldots \mathrm{O}(6) \# 3$ & 0.85 & 2.10 & $2.798(6)$ & 139.6 \\
$\mathrm{O}(9)-\mathrm{H}(9 \mathrm{AO}) \ldots \mathrm{O}(4)$ & 0.85 & 2.35 & $2.764(5)$ & 110.5 \\
$\mathrm{~N}(12)-\mathrm{H}(12 \mathrm{~N}) \ldots \mathrm{O}(9) \# 3$ & 0.88 & 1.92 & $2.776(5)$ & 162.7 \\
$\mathrm{~N}(10)-\mathrm{H}(10 \mathrm{~N}) \ldots \mathrm{O}(5) \# 4$ & 0.88 & 1.90 & $2.778(4)$ & 176.1 \\
$\mathrm{~N}(6 \mathrm{~A})-\mathrm{H}(6 \mathrm{AN}) \ldots \mathrm{O}(10) \# 3$ & 0.88 & 2.08 & $2.960(9)$ & 175.2 \\
$\mathrm{~N}(2)-\mathrm{H}(2 \mathrm{~N}) \ldots \mathrm{O}(5) \# 5$ & 0.88 & 1.81 & $2.688(4)$ & 173.1 \\
\hline
\end{tabular}

within the acceptable range. In complex 2 , all bond angles around the $\mathrm{Zn}(\mathrm{II})$ tetrahedron are increased in the optimized structure except the $\mathrm{N}_{18}-\mathrm{Zn}_{1}-\mathrm{N}_{10}$ and $\mathrm{N}_{18}-\mathrm{Zn}_{1}-\mathrm{N}_{2}$ angles which are compressed. The disparity between these bond 
Table 5. Optimized geometrical parameters of complex 1.

\begin{tabular}{cccc}
\hline Bond & $\begin{array}{c}\text { Experimental } \\
\text { Length (A) }\end{array}$ & $\begin{array}{c}\text { Theoretical } \\
\text { Length (A) }\end{array}$ & $\begin{array}{c}\text { Difference between } \\
\text { Experimental and } \\
\text { Theoretical Lengths (A) }\end{array}$ \\
\hline $\mathrm{O}_{18}-\mathrm{Zn}_{9}$ & 1.957 & 1.967 & 0.010 \\
$\mathrm{O}_{23}-\mathrm{Zn}_{9}$ & 1.957 & 1.968 & 0.011 \\
$\mathrm{~N}_{10}-\mathrm{Zn}_{9}$ & 2.004 & 2.088 & 0.084 \\
$\mathrm{~N}_{7}-\mathrm{Zn}_{9}$ & 2.004 & 2.087 & 0.083 \\
& Experimental & Theoretical & Difference between \\
Experimentaland \\
Angle & Angle $\left(^{\circ}\right)$ & Angle $\left(^{\circ}\right)$ & 12.19 \\
$\mathrm{~N}_{10}-\mathrm{Zn}_{9}-\mathrm{N}_{7}$ & 103.34 & 115.86 & 4.06 \\
$\mathrm{~N}_{10}-\mathrm{Zn}_{9}-\mathrm{O}_{23}$ & 111.80 & 115.86 & 5.57 \\
$\mathrm{O}_{23}-\mathrm{Zn}_{9}-\mathrm{O}_{18}$ & 121.12 & 115.94 & \\
\hline
\end{tabular}

Table 6. Optimized geometrical parameters of complex 2.

\begin{tabular}{cccc}
\hline Bond & $\begin{array}{c}\text { Experimental } \\
\text { Length (A) }\end{array}$ & $\begin{array}{c}\text { Theoretical } \\
\text { Length (A) }\end{array}$ & $\begin{array}{c}\text { Difference between } \\
\text { Experimental and Theoretical } \\
\text { Lengths (A) }\end{array}$ \\
\hline $\mathrm{Zn}_{1}-\mathrm{N}_{26}$ & 1.962 & 1.998 & 0.036 \\
$\mathrm{Zn}_{1}-\mathrm{N}_{10}$ & 2.004 & 2.074 & 0.070 \\
$\mathrm{Zn}_{1}-\mathrm{O}_{3}$ & 1.992 & 2.016 & 0.024 \\
$\mathrm{Zn}_{1}-\mathrm{N}_{18}$ & 1.973 & 2.111 & 0.138 \\
\hline angles & Experimental & Theoretical & Angles $\left(^{\circ}\right)$ \\
$\mathrm{N}_{18}-\mathrm{Zn}_{1}-\mathrm{N}_{10}$ & 111.18 & 107.14 & $\begin{array}{c}\text { Difference between } \\
\text { and Theoretical angles }\left(^{\circ}\right)\end{array}$ \\
$\mathrm{N}_{2}-\mathrm{Zn}_{1}-\mathrm{O}_{26}$ & 111.34 & 119.90 & 4.03 \\
$\mathrm{~N}_{18}-\mathrm{Zn}_{1}-\mathrm{N}_{2}$ & 116.31 & 103.58 & 8.56 \\
$\mathrm{~N}_{2}-\mathrm{Zn}_{1}-\mathrm{N}_{10}$ & 105.20 & 117.96 & 12.73 \\
$\mathrm{~N}_{10}-\mathrm{Zn}_{1}-\mathrm{O}_{26}$ & 102.31 & 104.59 & 12.96 \\
\hline
\end{tabular}

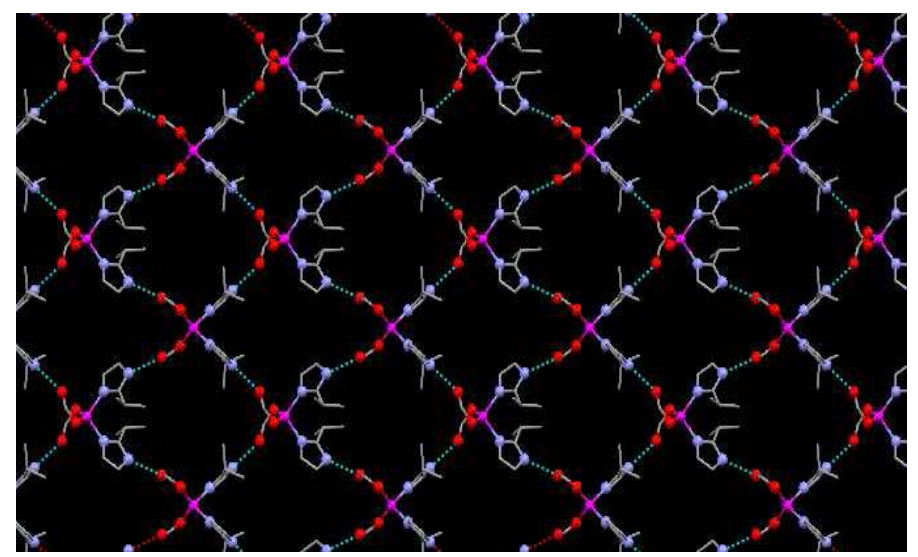

Figure 5. Two-dimensional structure of 1 containing pseudo-rectangular cavities. 


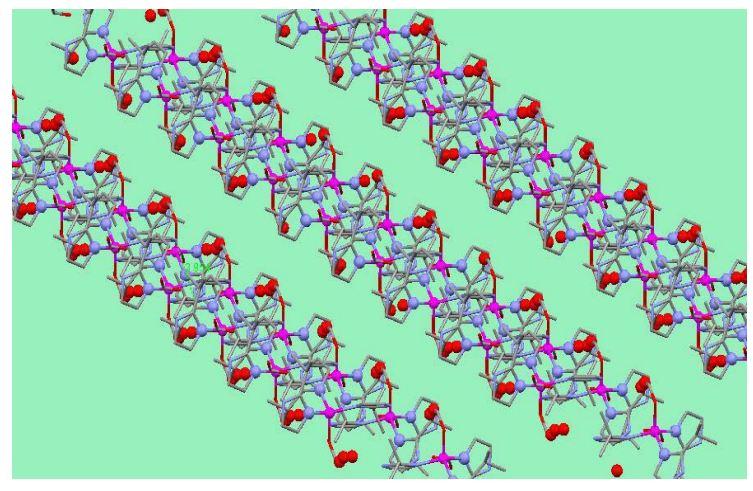

Figure 6. Two-dimensional crystalline lattice consisting of rectilinear pillars.

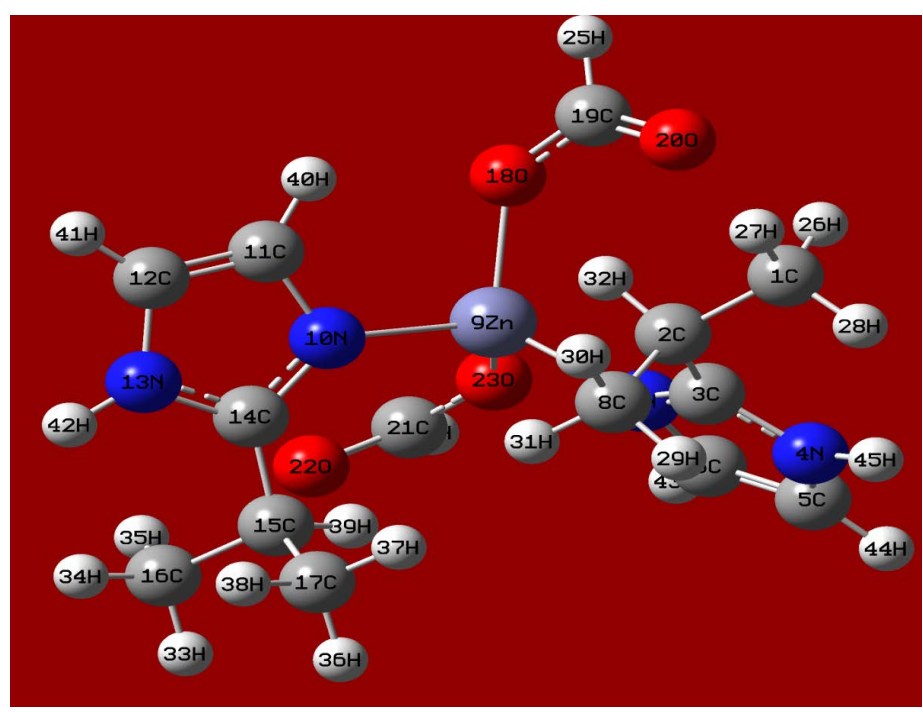

(a)

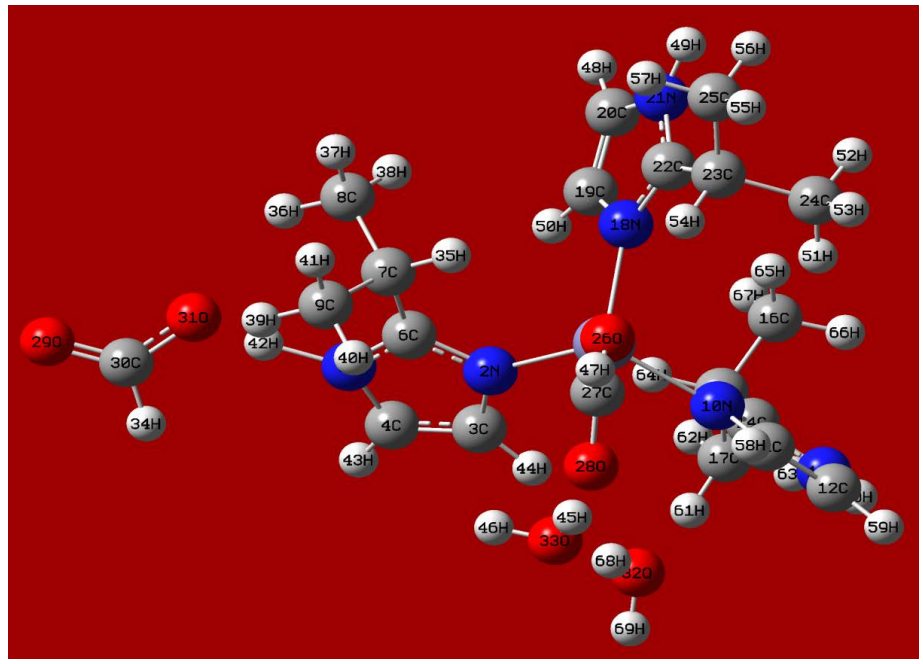

(b)

Figure 7. Optimized molecular structures of (a) Compounds 1 and (b) Compound 2, showing atomic labeling and the numbering scheme. 
angles in the experimental and the theoretical structures (between $2.28^{\circ}-8.56^{\circ}$ ) are acceptable except for the $\mathrm{N}_{18}-\mathrm{Zn}_{1}-\mathrm{N}_{2}$ and $\mathrm{N}_{2}-\mathrm{Zn}_{1}-\mathrm{N}_{10}$ which are exaggerated. That is, while the $\mathrm{N}_{18}-\mathrm{Zn}_{1}-\mathrm{N}_{2}$ angle is compressed from $116.31^{\circ}$ in the experimental structure to $103.58^{\circ}$ in the optimized with a difference of $12.73^{\circ}$, the $\mathrm{N}_{2}-\mathrm{Zn}_{1}-\mathrm{N}_{10}$ angle is enlarged from $105.20^{\circ}$ in the experimental structure to $117.96^{\circ}$ in the theoretical structure, giving a disparity of $12.96^{\circ}$. The frontier molecular orbitals (HOMO and LUMO) of both complexes were also computed using the Lanl2DZ basis set at the B3LYP level. The results obtained are shown on Figure 8. The energies and electron densities of these orbitals are important tools used in describing the chemical reactivity and excitation properties. Recently the energy gap between HOMO and LUMO has been used to prove the bioactivity of a molecule from intramolecular charge transfer [21]. Compound 1 has 260 molecular orbitals, 89 occupied and 172 unoccupied. The highest occupied molecular orbital, the $89^{\text {th }}$ has an energy of $-6.207 \mathrm{eV}$ while the lowest unoccupied molecular orbital, the $90^{\text {th }}$ has an energy of $-0.181 \mathrm{eV}$. Compound 2 has 370 molecular orbitals, of which 129 are occupied and 241 are unoccupied. The highest occupied molecular orbital of 2 is the $129^{\text {th }}$, with an energy of -5.543 $\mathrm{eV}$, while the lowest unoccupied molecular orbital which is $130^{\text {th }}$ has an energy of $-0.855 \mathrm{eV}$. The red colors on these orbitals show the positive phases while the

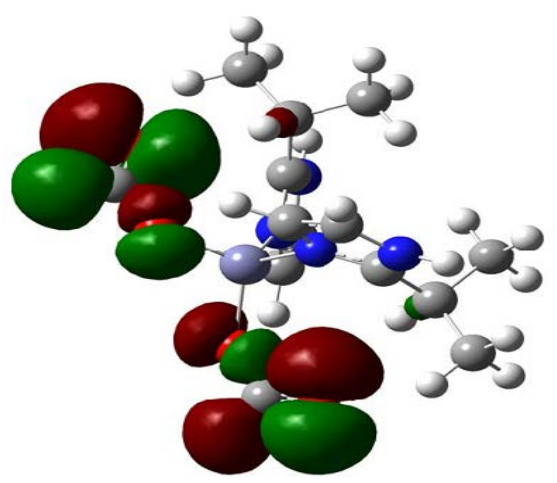

(a)

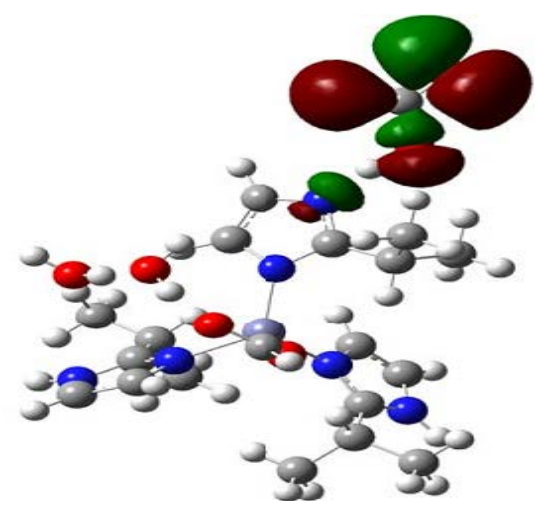

(c)

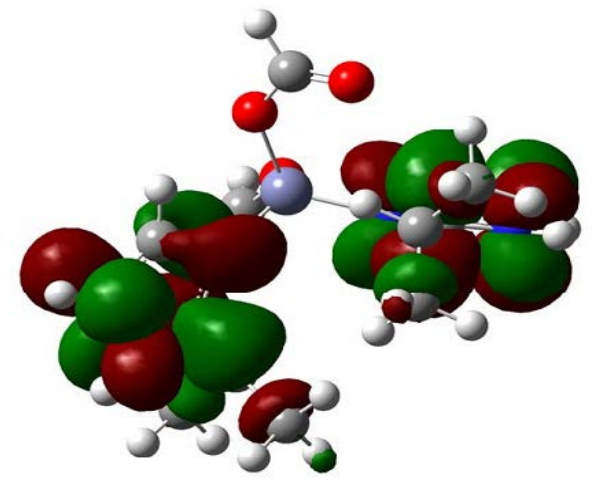

(b)

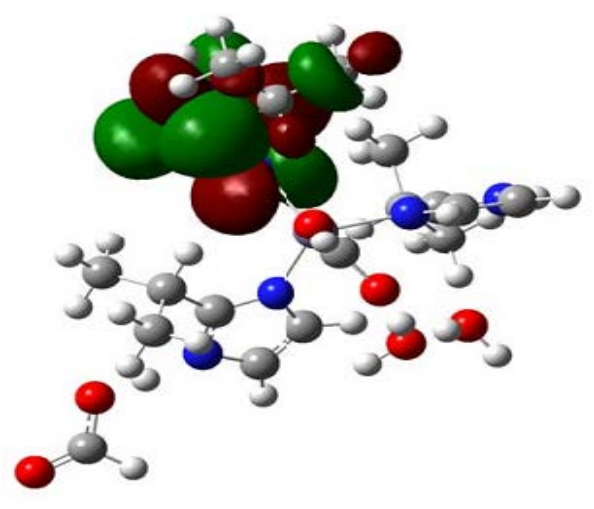

(d)

Figure 8. The ground state contour plots for the frontier molecular orbitals (a) HOMO $\left(\mathrm{E}_{\mathrm{HOMO}}=-6.207 \mathrm{eV}\right)$; (b) LUMO $\left(\mathrm{E}_{\mathrm{LUMO}}=-0.181 \mathrm{eV}\right)$ of compound 1 ; (c) HOMO $\left(\mathrm{E}_{\mathrm{HOMO}}=\right.$ $-5.543 \mathrm{eV})$; (d) LUMO ( $\left.\mathrm{E}_{\mathrm{LUMO}}=-0.855 \mathrm{eV}\right)$ of compound 2 . 
green colors represent the negative phases [22]. The figure shows that major contributions to the HOMO of complex 1 are made by the formate ligands while the main contributions to the HOMO in compound 2 are made by one water molecule of crystallization. However, some small contributions to the HOMO of 2 were observed from the $-\mathrm{C}=\mathrm{N}$ nitrogen atom of one imidazolyl fragment. Furthermore, major contributions to the LUMO of 1 came from the three 2-isopropylimidazolyl ligands meanwhile the major contributions to the LUMO of 2 were made by only one 2-isopropylimidazole fragment of the molecule. The global reactive descriptors of both complexes (Table 7) were obtained using the $\mathrm{E}_{\text {номо }}$ and $\mathrm{E}_{\mathrm{LUMO}}$. The global reactivity descriptors predict the reactivity and kinetic stability of a chemical special. In fact, molecules with large frontier molecular orbital gap or high values of chemical hardness are generally considered as hard molecules and are characterized by less polarizability, high kinetic stability and low chemical reactivity. Contrarily, molecules with small frontier molecular orbital gap or low values of chemical hardness are termed soft molecules. Such molecules are characterized by high degree of polarizability, low kinetic stability and high chemical reactivity. It is observed from Table 7 that compound 1 has a higher frontier molecular orbital gap and a higher value of chemical hardness than compound $\mathbf{2}$. Thus compound $\mathbf{2}$ is a softer molecule which is easily polarizable, with a low kinetic stability and a higher reactivity than complex 1 . This implies that the replacement of one formate group in bisformatobis(2-isopropylimidazole)zinc(II) (1) by a 2-isopropylimidazole unit couple with the presence of one formate counter ion and two hydrated water molecules in its unit cell increases the reactivity of the complex. This is achieved by the reduction of the frontier molecular orbital energy gap by $1.338 \mathrm{eV}$ and the decrease of its chemical hardness by $0.669 \mathrm{eV}$. Moreover, the analysis of the molecular electrostatic potential map shows that the formate ligands of 1 offer sites for electrophilic attack while in complex 2 , the counter fomate anion is the only site susceptible to attack by electrophiles. Furthermore, the theoretical vibrational frequencies and corresponding assignments of the complexes were investigated using the LanL2DZ basis set and the results obtained are shown in Table 8. The O-H vibrations of complex 2 and the $\mathrm{N}-\mathrm{H}$ vibrations of both complexes are shifted to higher values compared to the values obtained experimentally. Meanwhile, the theoretical $\mathrm{C}=\mathrm{C}$ and $\mathrm{C}=\mathrm{N}$ of both complexes are close to the experimental values and to those reported in literature. In order to comprehend the role of intermolecular orbital interaction

Table 7. Global reactivity descriptors of the complexes.

\begin{tabular}{ccc}
\hline & Compound 1 & Compound 2 \\
\hline Ionization energy $(\mathrm{I})(\mathrm{eV})$ & 6.207 & 5.543 \\
Electron affinity $(\mathrm{A})(\mathrm{eV})$ & 0.181 & 0.855 \\
Chemical potential $(\mu)(\mathrm{eV})$ & -3.194 & -3.199 \\
Chemical hardness $(\eta)(\mathrm{eV})$ & 3.013 & 2.344 \\
Energy gap $(\mathrm{eV})$ & 6.026 & 4.688 \\
Electrophilicity index $(\omega)(\mathrm{eV})$ & 1.690 & 2.182 \\
\hline
\end{tabular}


Table 8. Calculated IR vibrational frequencies of the complexes and their assignment.

\begin{tabular}{|c|c|c|}
\hline Vibrational Assignment & $\begin{array}{c}\text { Complex } 1 \\
\left.\text { (Frequency }\left(\mathrm{cm}^{-1}\right)\right)\end{array}$ & $\begin{array}{c}\text { Complex } 2 \\
\left(\text { Frequency }\left(\mathrm{cm}^{-1}\right)\right)\end{array}$ \\
\hline $\bar{v}(\mathrm{O}-\mathrm{H}) w a t$, as & l & 3797 \\
\hline $\bar{v}(\mathrm{~N}-\mathrm{H}) \mathrm{im}, s$ & 3689 & 3685 \\
\hline $\bar{v}(\mathrm{C}-\mathrm{H}) \mathrm{im}, s$ & 3688 & 3345 \\
\hline $\bar{v}(\mathrm{C}-\mathrm{H})$ form, $s$ & l & 3054.14 \\
\hline $\bar{v}(\mathrm{C}-\mathrm{H})$ iso, as & 3140.37 & l \\
\hline $\bar{v}(\mathrm{C}-\mathrm{H}) i s o, s s$ & I & 3034 \\
\hline $\bar{v}(\mathrm{O}-\mathrm{H})$ uncoord.wat, sci & I & 1707 \\
\hline $\bar{v}(\mathrm{C}=\mathrm{C}) i m, s$ & 1589 & 1516 \\
\hline $\bar{v}(\mathrm{C}=\mathrm{N}) \operatorname{im}, s$ & I & 1485 \\
\hline$\overline{\mathrm{v}}(\mathrm{C}-\mathrm{H})$ iso, $r$ & I & 1425.88 \\
\hline$\overline{\mathrm{v}}(\mathrm{C}-\mathrm{N}) \mathrm{im}, s$ & 1145 & 1482 \\
\hline $\bar{v}(\mathrm{Zn}-\mathrm{O}) s$ & 385 & 381 \\
\hline
\end{tabular}

v̄: vibration, wat: water, Iso: isopropyl, uncoord: uncoordinated, im: imidazole, form: formate s: stretching, as: asymmetric stretching, ss: symmetric stretching, r: rocking.

in the material in terms of charge transfer, Natural Bond Orbital (NBO) analyses were carried out on both complexes. This was achieved by considering all possible interactions between filled donor and empty acceptor NBOs and by estimating their energetic importance by second-order perturbation theory [23]. NBO analysis effectively studies intra and intermolecular binding through the examination of the degree of delocalization of electrons that usually occurs when ligand orbitals overlap with metal orbitals. When the interaction between the electron donor and electrons acceptor is strong, there is a greater extent of conjugation. This is often characterized by high values of the stabilization energy, $E^{(2)}$. The stabilization energies, $E^{(2)}$ for the most important intramolecular charge transfer interactions are summarized in Table 9 for compound 1 and Table 10 for compound 2. The donation of lone pair of electrons from N7 to an anti-bonding orbital of $\mathrm{Zn} 9$ in compound 1 was accompanied by an electron delocalization of 0.283 leading to the stabilization of the molecule by 33.070 $\mathrm{kcal} / \mathrm{mol}$. Meanwhile, the donation of the lone pair of electrons from Zn9 stabilized the molecule by $33.130 \mathrm{kcal} / \mathrm{mol}$ with a delocalization of 0.283 . Furthermore, the donation of the second lone pair of electrons from O18 to $\mathrm{LP}^{\star}(6) \mathrm{Zn}_{9}$ and $\mathrm{LP}^{\star}(7) \mathrm{Zn}_{9}$ induced a stabilization energy of $30.750 \mathrm{kcal} / \mathrm{mol}$ and 22.860 $\mathrm{kcal} / \mathrm{mol}$ respectively. It was also observed that the donation of the second lone pair of electrons from $\mathrm{O} 23$ to $\mathrm{LP}^{\star}(6) \mathrm{Zn}_{9}$ and $\mathrm{LP}^{\star}(7) \mathrm{Zn}_{9}$ stabilized the molecule by $30.460 \mathrm{kcal} / \mathrm{mol}$ and $23.120 \mathrm{kcal} / \mathrm{mol}$ respectively. Other strong interactions noticed in this complex involved the donation of a second lone pair of electrons from $\mathrm{O} 20$ to the anti-bonding orbital, $\pi^{\star} \mathrm{O} 18-\mathrm{C} 19$. This led to an electron delocalization of 0.064 and a stabilization energy of $72.970 \mathrm{kcal} / \mathrm{mol}$. The donation of the third lone pair of electrons from $\mathrm{O} 23$ to $\pi^{\star} \mathrm{C}_{21}-\mathrm{O}_{22}$ anti-bonding orbital stabilized the molecule by $71.700 \mathrm{kcal} / \mathrm{mol}$ while the donation of the first lone 
Table 9. Stabilization energies $\mathrm{E}^{(2)}(\mathrm{kcal} / \mathrm{mol})$ of the most important charge transfer interactions (donor - acceptor) of compound 1.

\begin{tabular}{|c|c|c|c|c|c|c|}
\hline Donor (i) & $\mathrm{ED}(\mathrm{i})$ & Acceptor (j) & $\mathrm{ED}(\mathrm{j})$ & $\mathrm{E}^{(2)} \mathrm{Kcal} / \mathrm{mol}$ & $E(j)-E(i)$ a.u & F(ij) a.u \\
\hline $\mathrm{LP}(1) \mathrm{N}_{4}$ & 1.580 & $\pi^{\star} \mathrm{C} 3-\mathrm{N}_{7}$ & 0.420 & 59.810 & 0.270 & 0.112 \\
\hline $\mathrm{LP}(1) \mathrm{N} 4$ & 1.580 & $\pi^{\star} \mathrm{C} 5-\mathrm{C} 6$ & 0.016 & 28.200 & 0.300 & 0.086 \\
\hline$\pi^{*} \mathrm{C} 3-\mathrm{N} 7$ & 0.420 & $\pi^{*} \mathrm{C} 5-\mathrm{C} 6$ & 0.016 & 33.130 & 0.030 & 0.052 \\
\hline $\mathrm{LP}(1) \mathrm{N}_{7}$ & 1.847 & $\mathrm{LP}^{\star}(6) \mathrm{Zn}_{9}$ & 0.283 & 33.070 & 0.570 & 0.127 \\
\hline $\operatorname{LP}(1) \mathrm{N}_{10}$ & 1.847 & $\mathrm{LP}^{\star}(6) \mathrm{Zn} 9$ & 0.283 & 33.130 & 0.570 & 0.127 \\
\hline $\mathrm{LP}(1) \mathrm{N}_{13}$ & 1.580 & $\pi^{*} \mathrm{~N} 10-\mathrm{C} 14$ & 0.027 & 59.880 & 0.270 & 0.112 \\
\hline $\operatorname{LP}(1) \mathrm{N}_{13}$ & 1.580 & $\pi^{\star} \mathrm{C} 11-\mathrm{C} 12$ & 0.259 & 28.220 & 0.300 & 0.086 \\
\hline$\pi^{\star} \mathrm{N} 10-\mathrm{C} 14$ & 0.419 & $\pi^{\star} \mathrm{C} 11-\mathrm{C} 12$ & 0.259 & 33.281 & 0.030 & 0.052 \\
\hline $\mathrm{LP}(2) \mathrm{O} 18$ & 1.856 & $\mathrm{LP}^{\star}(6) \mathrm{Zn}_{9}$ & 0.028 & 30.750 & 0.700 & 0.136 \\
\hline $\mathrm{LP}(2) \mathrm{O} 18$ & 1.856 & $\mathrm{LP}^{\star}(7) \mathrm{Zn}_{9}$ & 0.133 & 22.860 & 0.700 & 0.113 \\
\hline $\mathrm{LP}(3) \mathrm{O} 18$ & 1.708 & $\pi^{*} \mathrm{C}_{19}-\mathrm{O}_{20}$ & 0.278 & 22.860 & 0.260 & 0.124 \\
\hline $\mathrm{LP}(2) \mathrm{O} 20$ & 1.886 & $\pi^{\star} \mathrm{O} 18-\mathrm{C} 19$ & 0.064 & 72.970 & 0.260 & 0.124 \\
\hline $\mathrm{LP}(2) \mathrm{O} 20$ & 1.886 & $\pi^{\star} \mathrm{O}_{18}-\mathrm{C}_{19}$ & 0.064 & 21.510 & 0.660 & 0.108 \\
\hline $\mathrm{LP}(2) \mathrm{O}_{23}$ & 1.856 & $\mathrm{LP}^{\star}(6) \mathrm{Zn}_{9}$ & 0.283 & 30.460 & 0.700 & 0.135 \\
\hline $\mathrm{LP}(2) \mathrm{O}_{23}$ & 1.856 & $\mathrm{LP}^{\star}(7) \mathrm{Zn}_{9}$ & 0.132 & 23.120 & 0.700 & 0.114 \\
\hline $\mathrm{LP}(2) \mathrm{O} 22$ & 1.885 & $\pi^{\star} \mathrm{C}_{21}-\mathrm{O}_{23}$ & 0.064 & 21.540 & 0.660 & 0.108 \\
\hline $\mathrm{LP}(3) \mathrm{O} 23$ & 1.709 & $\pi^{\star} \mathrm{C}_{21}-\mathrm{O}_{22}$ & 0.276 & 71.700 & 0.260 & 0.123 \\
\hline
\end{tabular}

pair of electrons from N13 to $\pi^{*} \mathrm{~N} 10-\mathrm{C} 14$ caused a delocalization of 0.027 with a stabilization energy of $59.880 \mathrm{kcal} / \mathrm{mol}$. In compound 2, the donation of the first lone pair of electrons from $\mathrm{N} 2$ to the anti-bonding orbital of $\mathrm{Zn} 1$ stabilized the molecule by $41.970 \mathrm{kcal} / \mathrm{mol}$ with an electron delocalization of 0.290 , meanwhile, the donation of first lone pair of electrons from N10 to $\mathrm{Zn}$ anti-bonding orbital led to a delocalization of 0.291 and a stabilization energy of 32.580 $\mathrm{kcal} / \mathrm{mol}$. Furthermore the donation of the first lone pair of electrons from N18 and the second lone pair of electrons from $\mathrm{O} 26$ to an anti-bonding orbital of $\mathrm{Zn} 1$ was accompanied by a stabilization of $25.240 \mathrm{kcal} / \mathrm{mol}$ and $31.230 \mathrm{kcal} / \mathrm{mol}$ respectively. Some additional significant interactions observed in complex 2 included, $\pi \mathrm{C}_{3}-\mathrm{C}_{4}$ to $\mathrm{LP}(2) \mathrm{N}_{2}, \mathrm{LP}(2) \mathrm{N}_{2}$ to $\pi^{\star} \mathrm{N}_{5}-\mathrm{C}_{6}, \mathrm{LP}(1) \mathrm{N}_{5}$ to $\delta^{\star} \mathrm{O}_{31}-\mathrm{H}_{42}, \mathrm{LP}(1) \mathrm{N}_{13}$ to $\pi^{\star} \mathrm{N}_{10}-\mathrm{C}_{14}, \mathrm{LP}(1) \mathrm{N}_{21}$ to $\pi^{\star} \mathrm{N}_{18}-\mathrm{C}_{22}, \mathrm{LP}(3) \mathrm{O}_{26}$ to $\pi^{*} \mathrm{C}_{27}-\mathrm{O}_{28}$ and $\mathrm{LP}(2) \mathrm{O}_{31}$ to $\pi^{*} \mathrm{O} 29$-C30 with stabilization energies of $74.890,74.580,133.930,64.040,60.290$, 59.200 and $64.020 \mathrm{kcal} / \mathrm{mol}$ respectively. The values indicate the delocalization of electrons from the second lone pair of $\mathrm{N} 2$ to the neighboring N5-C6, first lone pair of $\mathrm{N} 13$ to the neighboring N10-C14, first lone pair of N21 to neighboring N18-C22, third lone pair of $\mathrm{O} 26$ to $\mathrm{C} 27-\mathrm{O} 28$ and the second lone pair of $\mathrm{O} 31$ to the neighboring $\mathrm{O} 29-\mathrm{C} 30$.

\section{Conclusion}

Two new zinc(II) complexes based on

2-isoproplylimidazole,bisformatobis(2-isopropylimidazole)zinc(II) (1) and formatotris(2-isopropylimidazole)zinc(II) formate-water (1/2) (2) have been synthesized and characterized in an attempt to modify the active site present in the 
Table 10. Stabilization energies $\mathrm{E}^{(2)}(\mathrm{kcal} / \mathrm{mol})$ of the most important charge transfer interactions (donor - acceptor) of compound 2.

\begin{tabular}{|c|c|c|c|c|c|c|}
\hline Donor (i) & $\mathrm{ED}(\mathrm{i})$ & Acceptor (j) & $E D(j)$ & $\mathrm{E}^{(2)} \mathrm{Kcal} / \mathrm{mol}$ & $E(j)-E(i) a u$ & $F(i j)$ a.u \\
\hline $\mathrm{LP}^{\star}(6) \mathrm{Zn}_{1}$ & 0.291 & $\mathrm{LP}^{\star}(7) \mathrm{Zn}_{1}$ & 0.094 & 52.930 & 0.01 & 0.050 \\
\hline $\mathrm{LP}(1) \mathrm{N} 2$ & 1.847 & $\mathrm{LP}^{\star}(6) \mathrm{Zn}_{1}$ & 0.290 & 41.970 & 0.530 & 0.138 \\
\hline$\pi \mathrm{C}_{3}-\mathrm{C}_{4}$ & 1.866 & $\mathrm{LP}(2) \mathrm{N}_{2}$ & 1.470 & 74.890 & 0.040 & 0.080 \\
\hline$\pi \mathrm{N}_{5}-\mathrm{C}_{6}$ & 1.871 & $\mathrm{LP}(2) \mathrm{N}_{2}$ & 1.470 & 26.430 & 0.080 & 0.071 \\
\hline $\operatorname{LP}(2) \mathrm{N}_{2}$ & 1.470 & $\pi^{*} \mathrm{C} 3-\mathrm{C}_{4}$ & 0.020 & 34.900 & 0.250 & 0.089 \\
\hline $\mathrm{LP}(2) \mathrm{N}_{2}$ & 1.470 & $\pi^{*} \mathrm{~N}_{5}-\mathrm{C}_{6}$ & 0.036 & 74.580 & 0.220 & 0.115 \\
\hline$\pi^{*} \mathrm{~N}_{5}-\mathrm{C}_{6}$ & 0.480 & $\pi^{\star} \mathrm{C} 3-\mathrm{C} 4$ & 0.304 & 45.340 & 0.030 & 0.055 \\
\hline $\mathrm{LP}(1) \mathrm{N}_{5}$ & 1.747 & $\delta^{*} \mathrm{O}_{31}-\mathrm{H}_{42}$ & 0.001 & 133.930 & 0.700 & 0.276 \\
\hline $\operatorname{LP}(1) \mathrm{N}_{10}$ & 1.860 & $\mathrm{LP}^{\star}(6) \mathrm{Zn}_{1}$ & 0.291 & 32.580 & 0.550 & 0.124 \\
\hline $\mathrm{LP}(1) \mathrm{N} 13$ & 1.570 & $\pi^{\star} \mathrm{N}_{10}-\mathrm{C}_{14}$ & 0.430 & 64.040 & 0.260 & 0.115 \\
\hline $\operatorname{LP}(1) N_{13}$ & 1.570 & $\pi^{*} \mathrm{C} 11-\mathrm{C} 12$ & 0.257 & 29.160 & 0.300 & 0.087 \\
\hline$\pi^{*} \mathrm{~N} 10-\mathrm{C} 14$ & 0.430 & $\pi^{*} \mathrm{C} 11-\mathrm{C} 12$ & 0.257 & 29.600 & 0.040 & 0.051 \\
\hline $\operatorname{LP}(1) \mathrm{N}_{18}$ & 1.869 & $\mathrm{LP}^{\star}(6) \mathrm{Zn} 1$ & 0.291 & 25.240 & 0.560 & 0.110 \\
\hline$\pi(2) \mathrm{N} 18-\mathrm{C} 22$ & 1.876 & $\pi^{*} \mathrm{C} 19-\mathrm{C} 20$ & 0.261 & 20.050 & 0.340 & 0.076 \\
\hline $\mathrm{LP}(1) \mathrm{N}_{21}$ & 1.577 & $\pi^{*} \mathrm{~N}_{18}-\mathrm{C}_{22}$ & 0.426 & 60.290 & 0.260 & 0.112 \\
\hline $\operatorname{LP}(1) \mathrm{N}_{21}$ & 1.577 & $\pi^{*} \mathrm{C}_{19}-\mathrm{C}_{20}$ & 0.261 & 28.610 & 0.300 & 0.086 \\
\hline$\pi^{*} \mathrm{~N}_{18}-\mathrm{C}_{22}$ & 0.426 & $\pi^{\star} \mathrm{C}_{19}-\mathrm{C}_{20}$ & 0.260 & 30.760 & 0.040 & 0.052 \\
\hline $\mathrm{LP}(2) \mathrm{O}_{26}$ & 1.881 & $\mathrm{LP}^{\star}(6) \mathrm{Zn}_{1}$ & 0.291 & 31.230 & 0.680 & 0.136 \\
\hline $\mathrm{LP}(3) \mathrm{O}_{26}$ & 1.693 & $\pi^{*} \mathrm{C}_{27}-\mathrm{O}_{28}$ & 0.062 & 59.200 & 0.300 & 0.120 \\
\hline $\mathrm{LP}(2) \mathrm{O}_{28}$ & 1.867 & $\delta^{*} \mathrm{O}_{33}-\mathrm{H}_{45}$ & 0.066 & 24.010 & 0.790 & 0.125 \\
\hline $\mathrm{LP}(2) \mathrm{O}_{26}$ & 1.881 & $\pi^{*} \mathrm{C}_{30}-\mathrm{O}_{31}$ & 0.076 & 25.550 & 0.620 & 0.114 \\
\hline $\mathrm{LP}(2) \mathrm{O} 31$ & 1.747 & $\pi^{*} \mathrm{O} 29-\mathrm{C} 30$ & 0.020 & 64.020 & 0.270 & 0.118 \\
\hline LP(2)O33 & 1.923 & $\pi^{\star} \mathrm{O}_{32}-\mathrm{H}_{68}$ & 0.068 & 36.160 & 0.970 & 0.168 \\
\hline
\end{tabular}

$\left({ }^{*}\right)$ indicates anti-bonding, $\mathrm{LP}(\mathrm{A})$ is a valence lone pair orbital on atom $\mathrm{A}, \mathrm{ED}$ is electron delocalization, $F(i, j)$ is the Fock matrix elements (a.u) between $i$ and $j$ NBO.

enzyme mimic, bisformatobis(2-isopropylimidazole)zinc(II) (1), by replacing one of its formate ligands by a 2 -isopropylimidazole group. This, we thought could be achieved by varying the molar ratio of zinc(II) formate-water (1/2) and 2-isopropylimidazole from 1:2 in 1 to $1: 4$ in 2 . Although the attempt was successful, the additional presence of one formate counter ion and two hydrated water molecules was observed in the crystal structure of 2 . This structural differences induced in these complexes, affected the electronic and physicochemical properties of the complexes. For instance, while compound 1 appeared thermally stable up to $100^{\circ} \mathrm{C}$, compound 2 was only stable up to $60^{\circ} \mathrm{C}$. Furthermore, the intra- and intermolecular interactions observed in these materials generated a two-dimensional leaf like crystalline network in structure 1 and a two-dimensional crystalline lattice of rectilinear pillars in 2 . The structural differences between 1 and $\mathbf{2}$ also reduced the frontier molecular orbital energy gap and the chemical hardness of compound 1 . Thus the reactivity of the modified 
enzyme mimic 2 was found to be greater than that of 1 . Finally, we realized that the modification of the active site present in complex 1 through the synthesis of complex 2 led to the reproduction of the active site present in another naturally existing enzyme, carbonic anhydrase, in which the Zn metal center is found in a pseudo-tetrahedral geometry built up by three nitrogen atoms from three histidine molecules and one oxygen atom from a coordinated water [24]. Meanwhile, the enzymatic effects this modification may have would be published in our future reports.

\section{Acknowledgements}

The authors are grateful to Prof E. Alvarez of Instituto de Investigaciones Quimicas (IIQ)-Universidad de Sevilla (Spain) for X-ray facilities and to Prof C. Pettinari of the University of Camerino (Italy) for spectroscopic and Thermogravimetric analyses facilities. We are also grateful for the "allocation spéciale pour la modernisation de la recherche universitaire" from the Ministry of Higher Education (Cameroon).

\section{Supplementary Material}

Detailed crystallographic data in CIF format has been deposited with the Cambridge Crystallographic Data Centre (CCDC number: 1850662-1850663). The data can be obtained free of charge at http://www.ccdc.cam.ac.uk/conts/retrieving.html [or from Cambridge Crystallographic Data Centre (CCDC), 12 Union Road, Cambridge CB2 IEZ, UK; fax: +44 (0) 1223-336033; e-mail: deposit@ccdc.cam.ac.uk].

\section{Conflicts of Interest}

The authors declare no conflicts of interest regarding the publication of this paper.

\section{References}

[1] Haanstra, W.G., Van der Donk, W.A., Driessen, W.L., Reedij, J., Drew, M.G.B. and Wood, J.S. (1990) Coordination Behaviour of the Ligand 1,9-bis(3,5-dimethyl-1pyrazolyl)-3,7-dithianonane (bddn) towards First-Row Transition Metals, X-Ray Structure of $[\mathrm{Cu}(\mathrm{bddn})(\mathrm{H}, \mathrm{O})](\mathrm{BF} 4) 2$. Inorganica Chimica Acta, I76, 299-305. https://doi.org/10.1016/S0020-1693(00)84860-4

[2] Parkin, G. (2004) Synthetic Analogues Relevant to the Structure and Function of Zinc Enzymes. Chemical Review, 104, 699-767. https://doi.org/10.1021/cr0206263

[3] Tosha, M.B., Ignacio, D.R., Robert, A. and Sarah, M.J. (2003) Oxazoline Chemistry-Part IV: Synthesis and Characterization of Oxazoline Complexes of the Zinc Halides. Canada Journal of Chemistry, 81, 1482-1491. https://doi.org/10.1139/v03-166

[4] Lipscomb, W.N. (1980) Carboxypeptidase A Mechanisms. Proceedings of the National Academy of Sciences, 77, 3875-3878. https://doi.org/10.1073/pnas.77.7.3875

[5] Lipscomb, W.N. (1982) Acceleration of Reactions by Enzymes. Accounts of Chemical Research, 15, 232-238. https://doi.org/10.1021/ar00080a001 
[6] Christianson, D.W. and Lipscomb, W.N. (1989) Carboxypeptidase A. Accounts of Chemical Research, 22, 62-69. https://doi.org/10.1021/ar00158a003

[7] Ondetti, M.A., Rubin, B. and Cushman, D.W. (1977) Design of Specific Inhibitors of Angiotensin-Converting Enzyme: New Class of Orally Active Antihypertensive Agents. Science, 196, 441-444. https://doi.org/10.1126/science.191908

[8] Gafford, J.T., Skidgel, R.A., Erdos, E.G. and Hersh, L.B. (1983) Human Kidney "Enkephalinase", a Neutral Metalloendopeptidase that Cleaves Active Peptides. Biochemistry, 22, 3265-3271. https://doi.org/10.1021/bi00282a035

[9] Kim, D.H., Guinosso, C.J., Buzby, G.C., Herbst, D.R., McCaully, R.J., Wicks, T.C. and Wendt, R.C. (1983) (Mercaptopropanoyl)indoline-2-carboxylic Acids and Related Compounds as Potent Angiotensin Converting Enzyme Inhibitors and Antihypertensive Agents. Journal of Medicinal Chemistry, 26, 394-403. https://doi.org/10.1021/jm00357a014

[10] Raymond, P.H. (1984) The Role of Carbonic Anhydrase in Blood Ion and Acid-Base Regulation. American Zoologist, 24, 241-251. https://doi.org/10.1093/icb/24.1.241

[11] Bradfield, J.R.G. (1947) Plant Carbonic Anhydrase. Nature, 159, 467-468. https://doi.org/10.1038/159467a0

[12] Wei-Hong, S., Yan-You, W., Zhen-Zhen, S., Qiu-Xia, W. and Xin-Yu, W. (2014) Enzymatic Characteristics of Higher Plant Carbonic Anhydrase and Its Role in Photosynthesis. Journal of Plant Studies, 3, 39-44. https://doi.org/10.5539/jps.v3n2p39

[13] Ngoune, J., Dzesse, C.N.T., Dongmo, G.C. and Tane, P. (2011) Compose Modele des Metalloproteines de Zinc: Synthese et Caracterisation du Complexe Bisformatobis(2-isopropylimidazole)zinc(II). Cameroon Journal of Experimental Biology, 7, 16-21. https://doi.org/10.4314/cajeb.v7i1.69787

[14] Ngnabeuye, N.O., Djampouo, T.A., Ndosiri. N.B., Fomuta, T.R., Golngar, D., Kuate, T.A.C. and Ngoune, J. (2018) Synthesis, Structural Characterization and Computational Studies of Bis(2-Ethylimidazole) Bis(Formato)Zinc(II)-Water (1/1). Crystal Structure Theory and Applications, 7, 1-18. http://www.scirp.org/journal/csta

[15] Bruker AXS Inc. (2007) APEX2. Madison, Wisconsin.

[16] Bruker (2004) Advanced X-Ray Solutions. SAINT and SADABS Programs. Bruker AXS Inc., Madison.

[17] Burla, M.C., Camalli, M., Carrozzini, B., Cascarano, G.L., Giacovazzo, C., Polidori, G. and Spagna, R. (2003) SIR2002. Journal of Applied Crystallography, 36, 1103. https://doi.org/10.1107/S0021889803012585

[18] Sheldrick, G.M. (2015) Crystal Structure Refinement with SHELXL. Acta Crystallographica C, 71, 3-8. https://doi.org/10.1107/S2053229614024218

[19] Amsterdam Density Functional (ADF) Version 2007.01 http://www.scm.com

[20] Ehlert, M.K., Rettig, S.J., Storr, A., Thompson, R.C. and Trotter, J. (1990) Zinc 3,5-dimethylpyrazolate Complexes: Synthesis and Structural Studies. The Crystal and Molecular Structure of $\left[\mathrm{Zn}_{2}(\mathrm{dmpz})_{4}(\mathrm{Hdmpz})_{2}\right]$. Canadian Journal of Chemistry, 68, 1494-1498. https://doi.org/10.1139/v90-229

[21] Marouani, H., Raouafi, N., Toumi Akriche, S., Al-Deyab, S.S. and Rzaigui, M. (2011) Synthesis, Crystal Structure and Computational Studies of 1-Phenylpiperazin-1,4-Diium Nitrate Monohydrate. Journal of Chemistry, 9, 772-779.

[22] Fomuta, T.R., Djimassingar, G., Ngoune, J., Ngnabeuye, N.O., Anguile, J.J. and Nenwa, J. (2017) Synthesis, Structural Characterization and DFT Studies of Silver (I) Complex Salt of Bis(4,5-dihydro-1H-benzo[g]indazole). Crystal Structure 
Theory and Application, 6, 11-24. https://doi.org/10.4236/csta.2017.62002

[23] Gangadharan, R.P. and Krishnan, S.S. (2014) Natural Bond Orbital (NBO) Population Analysis of 1-Azanapthalene-8-ol. Acta Physica Polonica A, 125, 18-22. https://doi.org/10.12693/APhysPolA.125.18

[24] Romieu, A. (2006) Rôle des ions métalliques en Biologie, Cours de Chimie Bio-Inorganique, IRCOF/LHO (UMR6014). Université de Rouen. 